\title{
Introduction to Polis Special Issue on Roman Political Thought
}

In 2019, the journal Polis expanded its scope to include articles on all aspects of Hellenistic and Roman political thought and their subsequent reception. This expansion was due, in part, to the fact that the ancient Mediterranean was a culturally and intellectually connected entity, and sharp distinctions between classical Greek, Hellenistic, and Roman political thought overlooked the many important relationships between these topics of inquiry. In addition, the expansion to include Roman thought came amid a wide array of recent research on Roman political thought from a number of disciplines, including political science, classics, history, philosophy, and law, to name but a few. ${ }^{1}$ This

1 We provide but a small selection of recent work in these disciplines, focusing only on English language publications. Political science: D. Kapust, Republicanism, Rhetoric, and Roman Political Thought: Sallust, Livy, and Tacitus (Cambridge: Cambridge University Press, 2011); G. Remer, Ethics and the Orator: The Ciceronian Tradition of Political Morality (Chicago: University of Chicago Press, 2017); D. Lee, Popular Sovereignty in Early Modern Constitutional Thought (Oxford: Oxford University Press, 2016); D. Hammer, Roman Political Thought and the Modern Theoretical Imagination (Norman, Oklahoma: University of Oklahoma Press, 2008); D. Hammer, Roman Political Thought: From Cicero to Augustine (Cambridge: Cambridge University Press, 2014); M. Clarke, 'Doing Violence to the Roman Idea of Liberty? Freedom as Bodily Integrity in Roman Political Thought', History of Political Thought, 35.2 (2014), pp. 211-33; M. C. Hawley, 'Individuality and Hierarchy in Cicero's De Officiis', European Journal of Political Theory, 15 (2016); D. Kapust and M. Schwarze, "The Rhetoric of Sincerity: Cicero and Smith on Propriety and Political Context', American Political Science Review, 110.1 (2016), pp. 100-11; W. Nicgorski, Cicero's Skepticism and His Recovery of Political Philosophy (New York: Palgrave Macmillan, 2016). Classics: M. Lowrie, Writing, Performance, and Authority in Augustan Rome (Oxford: Oxford University Press, 2009); N. Pandey, The Poetics of Power in Augustan Rome: Latin Poetic Responses to Early Imperial Iconography (Cambridge: Cambridge University Press, 2018); G. Nelsestuen, Varro the Agronomist: Political Philosophy, Satire, and Agriculture in the Late Republic (Columbus, Ohio: The Ohio State University Press, 2015); Y. Baraz, A Written Republic: Cicero's Philosophical Politics (Princeton: Princeton University Press, 2012); J. Atkins, Cicero on Politics and the Limits of Reason: the Republic and Laws (Cambridge: Cambridge University Press, 2013); J. Atkins, Roman Political Thought (Cambridge: Cambridge University Press, 2018); V. Arena, Libertas and the Practice of Politics in the Late Roman Republic (Cambridge: Cambridge University Press, 2012); T. Strunk, History After Liberty: Tacitus on Tyrants, Sycophants, and Republicans (Ann Arbor, Michigan: University of Michigan Press, 2016); S. McCarter, Horace between Freedom and Slavery: the 
resurgence of interest in Rome, given its particularly notable neglect in twentieth-century political theory, ${ }^{2}$ is related to a number of scholarly developments, including attention to Roman law and its relationship to early modern constitutionalism, the revival of interest in the ethical and political dimensions of rhetoric, ${ }^{3}$ and the emergence of republicanism within philosophy and political theory. ${ }^{4}$

We are very pleased, then, to publish these six articles by an interdisciplinary group of scholars, drawn from the disciplines of political science, classics, and law. Each contributor has published on Roman political thought, and each has contributed an article on the connection between Roman political thought and contemporary political, social, and ethical problems. Our goal was to bring together a group of scholars from a range of disciplines and career stages to address both the substantive importance of Roman thought across disciplines and its salience given contemporary concerns.

The order in which we offer these articles roughly reflects the chronological focus of each contribution. We begin with Benjamin Straumann's article,

First Book of Epistles (Madison, Wisconsin: University of Wisconsin Press, 2015); A. Dressler, Personification and the Feminine in Roman Philosophy (Cambridge: Cambridge University Press, 2016); J. Zarecki, Cicero's Ideal Statesman in Theory and Practice (London: Bloomsbury Publishing, 2014); S. R. Stem, The Political Biographies of Cornelius Nepos (Ann Arbor: University of Michigan Press, 2012); J. Connolly, The State of Speech: Rhetoric and Political Thought in Ancient Rome (Princeton: Princeton University Press, 2009); J. Connolly, The Life of Roman Republicanism (Princeton: Princeton University Press, 2015); A. Vasaly, Livy's Political Philosophy (Cambridge: Cambridge University Press, 2015). History: C. Ando, Imperial Ideology and Provincial Loyalty in the Roman Empire (Berkeley: University of California Press, 2000); T. P. Wiseman, Remembering the Roman People: Essays on Late-Republican Politics and Literature (Oxford: Oxford University Press, 2009); W. Scheidel, Escape from Rome: The Failure of Empire and the Road to Prosperity (Princeton: Princeton University Press, 2019). Philosophy: R. Woolf, Cicero: The Philosophy of a Roman Sceptic (New York and London: Routledge, 2015); E. Asmis, 'A New Kind of Model: Cicero's Roman Constitution in De republica', The American Journal of Philology, 126.3 (2005), pp. 377-416; E. Asmis, 'Lucretius' New World Order: Making a Pact with Nature', The Classical Quarterly, 58.1 (2008), pp. 141-57; T. Lockwood, 'Defining Friendship in Cicero's de amicitia', Ancient Philosophy (forthcoming). Law: B. Straumann, Roman Law in the State of Nature: The Classical Foundations of Hugo Grotius' Natural Law (Cambridge: Cambridge University Press, 2015); B. Straumann, Crisis and Constitutionalism: Roman Political Thought from the Fall of the Republic to the Age of Revolution (Oxford: Oxford University Press, 2016).

2 On the decline of interest in Rome, see D. Hammer, Roman Political Thought and the Modern Theoretical Imagination, Chapter 1.

3 On rhetoric in contemporary ethical and political theory, see B. Garsten, 'The Rhetoric Revival in Political Theory', Annual Review of Political Science, 14 (2011), pp. 159-80.

4 On republicanism, see F. Lovett and P. Pettit, 'Neorepublicanism: A Normative and Institutional Research Program', Annual Review of Political Science, 12 (2009), pp. 11-29. 
'Leaving the State of Nature: Polybius on Resentment and the Emergence of Morals and Political Order'. Straumann makes the case for a game theoretic reading of Polybius. He argues that Polybius' account of the Roman constitution, emerging through a moral genealogy rooted in the micro-foundations of a philosophical anthropology, is a solution to moral and political problems associated with stability and political order. Through a comparative reading of Polybius with the later thinkers Thomas Hobbes, David Hume, and Adam Smith, Straumann shows that Polybius' understanding of constitutional order enables the emergence of a distinctive form of moral reasoning.

In "The Protectorate of the World": the Problem of Just Hegemony in Roman Thought', Michael Hawley brings the writings of ancient Romans into dialogue with contemporary discussions of the ethics of hegemonic power. Drawing on the writings of Cicero, Caesar, and Tacitus to identify two models of imperial power - one that he calls a 'universal protectorate', the other an 'empire of justice' - Hawley argues that each recognised that considerations of justice ought to play a critical role in the otherwise self-interested wielding of power. Hawley's article provides fertile ground for thinking through the position and responsibilities of contemporary hegemonic power from a normative perspective.

In her contribution, 'Between Rhetoric, Social Norms, and Law: Liberty of Speech in Republican Rome', Valentina Arena turns to the question of why, in spite of the arguments of contemporary republican theorists such as Philip Pettit, Rome never implemented formal protections for equal and free speech. Drawing on the distinction between libertas and licentia, along with a wide array of Roman sources, Arena argues that speech was understood to be a natural and distinctive human capacity, and that speaking freely was fundamentally a moral quality, and not a right requiring legal protection. While the Roman republic would have fallen short of the contemporary republican normative ideal, the experience of the Roman republic invites us to think about free speech as a function of social norms.

Dean Hammer, in 'The Roman Republic and the Crisis of American Democracy: Echoes of the Past', turns to a key puzzle in the historiography of the late republic: why did the republic collapse when no individual seems to have intended to bring about its downfall? Rather than turn to structural or individual level explanations, Hammer develops a phenomenological account that focuses on the decreasing ability of Roman institutions to project the Roman community into the future. This decrease was, in turn, rooted in changes in the norms that had sustained these institutions and made them effective in the first place. The most visible of these changes was the elevation of individuals who sought to circumvent apparently dysfunctional 
institutions, an elevation that was enabled and legitimised by the loss of normative consensus.

In 'Ovid, the Res Publica, and the "Imperial Presidency": Public Figures and Popular Freedoms in Augustan Rome and America', Nandini B. Pandey provides an original reading of the Roman poet best known for his mythographical, often lascivious poetry. Writing in the late first-century ВСЕ and early first-century $\mathrm{CE}$, Ovid provides invaluable evidence for the way that traditional 'republican' ideas evolved and continued to resonate even under the emergence of the autocracy of Augustus - Rome's first 'emperor' who, by his own account, restored Rome's res publica. Moreover, grasping the 'range of perspectives' on res publica that Ovid offers throughout his massive oeuvre, Pandey sheds light on questions of privacy, publicity, and the role of the media, all of which have become increasingly central to modern politics, especially in the age of the 'imperial presidency' in the United States.

In the final contribution, "Tertullian on "The Freedom of Religion", Jed W. Atkins considers the question of religious liberty in the writings of Tertullian, the late-second/early-third century CE North African Christian writer. Beyond coining the phrase 'the freedom of religion' itself, Tertullian, Atkins argues, appropriates the Roman republican idea of libertas as 'non-domination' for the theoretical underpinnings to his account of religious liberty. Paving the way for the extension of non-domination to other realms (e.g. the religious) and regime types (e.g. monarchy), Tertullian anticipates later treatments of individual 'conscience' within the liberal tradition, which shows him to be the 'first political theologian' in the western tradition.

Each of these pieces is not only representative of a particular disciplinary approach to Roman thought and its contemporary ethical and political significance, but also suggests future avenues for research into topics such as executive power, liberty, empire, international relations, republicanism, the relationship between institutions and norms, and game-theoretic approaches to political philosophy, among other topics.

\author{
Grant Nelsestuen \\ University of Wisconsin-Madison, Madison, WI, USA \\ nelsestuen@wisc.edu
}

\title{
Daniel Kapust
}

University of Wisconsin-Madison, Madison, WI, USA

djkapust@wisc.edu 